\title{
Belief in Family Planning Myths at the Individual And Community Levels and Modern Contraceptive Use in Urban Africa
}

\begin{abstract}
CONTEXT: Negative myths and misconceptions about family planning are a barrier to modern contraceptive use. Most research on the subject has focused on individual beliefs about contraception; however, given that myths spread easily within communities, it is also important to examine how the prevalence of negative myths in a community affects the aggregate level of method use.
\end{abstract}

METHODS: Baseline data collected in 2010-2011 by the Measurement, Learning \& Evaluation project on women aged 15-49 living in selected cities in Kenya, Nigeria and Senegal were used. Multivariate analyses examined associations between modern contraceptive use and belief in negative myths for individuals and communities.

RESULTS: In each country, the family planning myths most prevalent at the individual and community levels were that "people who use contraceptives end up with health problems," "contraceptives are dangerous to women's health" and "contraceptives can harm your womb." On average, women in Nigeria and Kenya believed 2.7 and 4.6 out of eight selected myths, respectively, and women in Senegal believed 2.6 out of seven. Women's individual-level belief in myths was negatively associated with their modern contraceptive use in all three countries (odds ratios, 0.2-0.7). In Nigeria, the women's community-level myth variable was positively associated with modern contraceptive use (1.6), whereas the men's community-level myth variable was negatively associated with use (0.6); neither community-level variable was associated with modern contraceptive use in Kenya or Senegal.

CONCLUSION: Education programs are needed to dispel common myths and misconceptions about modern contraceptives. In Nigeria, programs that encourage community-level discussions may be effective at reducing myths and increasing modern contraceptive use.

International Perspectives on Sexual and Reproductive Health, 2015, 41(4):191-199, doi: 10.1363/4119115

Unmet need for family planning-defined as the proportion of women in union who are sexually active and fecund, and want to delay childbearing for at least two years or cease childbearing altogether, but are not using any method of contraception ${ }^{1,2}$-is high throughout SubSaharan Africa. ${ }^{3}$ Many women and couples with unmet need for either spacing or limiting births do not practice contraception because they lack adequate knowledge of the social, economic and health benefits of family planning, do not know which methods are available or appropriate for them, or do not know where to obtain a method. ${ }^{4}$ Others are discouraged from using a method because they believe that their partner, family, community or religion is opposed to contraception.

Another important barrier to contraceptive use is myths and misconceptions about modern methods, such as exaggerated or erroneous reports about side effects, misconceptions about short- or long-term health problems and negative stereotypes about persons who practice family planning, ${ }^{5,6}$ For example, in both developed and developing countries, many women incorrectly perceive use of oral contraceptives to be more dangerous than pregnancy. ${ }^{7}$ In a study of eight developing countries, $50-70 \%$ of women thought that using the pill posed considerable health risks. ${ }^{8}$ According to a study in Mali, many women feared that the pill and the injectable could cause permanent infertility. ${ }^{9}$ A qualitative study in Kenya among sexually active women aged 15-25 demonstrated that many women had misconceptions about the side effects of modern contraceptives (e.g., that they cause infertility or can harm a woman's uterus), but few had experienced or knew someone who had experienced an actual side effect (e.g., weight gain). ${ }^{10}$ In another qualitative study in Kenya among reproductive-age women, one respondent reported that the pill "can accumulate into a life-threatening mass in the stomach, can cause blood to flow out of the nose and mouth, and can cause delivery of children with two heads and no skin." ${ }^{\text {"l }}$ Myths and misconceptions about methods can spread through informal communication via social networks and lead to continued negative perceptions. ${ }^{12,13}$

The prevalence of such myths and misconceptions has been demonstrated in several national-level studies ${ }^{3,14,15}$ and in rural areas. ${ }^{16}$ Data from the Measurement, Learning $\&$ Evaluation (MLE) project from Kenya, Nigeria and Senegal demonstrate high levels of misinformation about family planning in urban areas. ${ }^{17-19}$ In MLE baseline surveys conducted between 2010 and 2011, at least half of the women interviewed in six cities in Senegal believed that contracep-

\section{By Abdou Gueye, llene S. Speizer, Meghan Corroon and Chinelo $C$. Okigbo}

Abdou Gueye is country manager, Measurement, Learning $\&$ Evaluation project, IntraHealth International, Dakar, Senegal. Ilene S. Speizer is research professor and Chinelo C. Okigbo is a doctoral candidate, both with the Department of Maternal and Child Health, Gillings School of Global Public Health, University of North Carolina at Chapel Hill, USA. Meghan Corroon is technical officer, Measurement, Learning E Evaluation Project, Carolina Population Center, University of North Carolina at Chapel Hill. 
TABLE 1. Percentage distributions of women aged 15-49 from selected cities in Kenya, Nigeria and Senegal, by characteristics, Measurement, Learning \& Evaluation project, 2010-2011

\begin{tabular}{|c|c|c|c|}
\hline Characteristic & $\begin{array}{l}\text { Kenya } \\
(\mathrm{N}=5,588)\end{array}$ & $\begin{array}{l}\text { Nigeria } \\
(\mathrm{N}=8,880)\end{array}$ & $\begin{array}{l}\text { Senegal } \\
(N=4,952)\end{array}$ \\
\hline \multicolumn{4}{|l|}{ Age } \\
\hline $15-19$ & 10.2 & 14.0 & 18.7 \\
\hline $20-24$ & 29.2 & 17.2 & 22.1 \\
\hline $25-29$ & 24.6 & 20.7 & 18.3 \\
\hline $30-34$ & 15.0 & 17.6 & 14.3 \\
\hline $35-39$ & 10.6 & 14.1 & 12.3 \\
\hline $40-44$ & 6.5 & 9.4 & 8.8 \\
\hline $45-49$ & 3.9 & 7.1 & 5.6 \\
\hline \multicolumn{4}{|l|}{ Education } \\
\hline None/Quranic & 5.9 & 8.4 & 30.9 \\
\hline Primary & 36.4 & 14.3 & 33.4 \\
\hline Secondary & 39.8 & 48.0 & 29.0 \\
\hline >secondary & 17.9 & 28.6 & 6.7 \\
\hline Missing & 0.0 & 0.7 & 0.0 \\
\hline \multicolumn{4}{|l|}{ Religion } \\
\hline Muslim & 9.8 & 48.2 & 89.7 \\
\hline Non-Muslim & 90.1 & 51.2 & 10.3 \\
\hline Missing & 0.1 & 0.6 & 0.0 \\
\hline \multicolumn{4}{|l|}{ Marital status } \\
\hline Never married & 32.9 & 31.6 & 39.7 \\
\hline Ever married & 67.1 & 68.4 & 60.3 \\
\hline \multicolumn{4}{|l|}{ Wealth quintile } \\
\hline Poorest & 17.0 & 16.4 & 18.7 \\
\hline Second & 19.4 & 18.7 & 19.2 \\
\hline Middle & 19.5 & 19.9 & 19.8 \\
\hline Fourth & 20.8 & 21.4 & 19.4 \\
\hline Richest & 23.4 & 23.6 & 22.9 \\
\hline \multicolumn{4}{|l|}{ City of residence } \\
\hline Dakar/Abuja/Nairobi & 74.8 & 17.4 & 48.8 \\
\hline Guédiawaye/Ibadan/Mombasa & 19.8 & 29.6 & 12.6 \\
\hline Pikine/llorin/Kisumu & 5.4 & 23.6 & 13.2 \\
\hline Mbao/Kaduna/na† & nat & 29.4 & 25.3 \\
\hline \multicolumn{4}{|l|}{ Use of modern method $¥$} \\
\hline Yes & 42.1 & 26.5 & 16.9 \\
\hline No & 57.9 & 73.5 & 83.1 \\
\hline Total & 100.0 & 100.0 & 100.0 \\
\hline
\end{tabular}

tna $=$ not applicable. $¥$ Modern methods include the pill, IUD, injectable, implant, emergency contraceptive pills, lactational amenorrhea method, condoms (male and female), spermicide, diaphragm or sterilization (male and female). Note: All percentages are weighted and based on analytic samples that exclude women with missing data and those from primary sampling units with fewer than five observations.

tive users will have health problems; ${ }^{19}$ similar results were found among men. Across six Nigerian cities, the proportion of women who believed that myth ranged from 33\% in Abuja to $57 \%$ in Ibadan; ${ }^{18}$ the proportion among men was 25-48\%. And in Kenya, 65-82\% of women and men in the five study cities thought that contraception is dangerous to one's health. ${ }^{17}$ At midterm MLE evaluations two years after baseline, these myths persisted among women in the three countries, although there was a slight decline. ${ }^{20-22}$

Inadequate and incorrect knowledge of modern contraceptives has been associated with low method uptake and use, ${ }^{23}$ however, even in settings where knowledge of family planning is high, myths and misconceptions are associated with low demand for and use of contraceptives. ${ }^{3,23}$ A study of 2006-2013 Demographic and Health Survey (DHS) data assessed reasons for contraceptive nonuse and found that, in 26 of the 51 countries studied, $20-50 \%$ of women who were married or in a union and at risk of unintended pregnancy reported fear of side effects and fear of health problems as their principal reasons for not practicing family planning. ${ }^{3}$ Furthermore, among women with unmet need in Sub-Saharan African countries, 28\% reported side effects and health problems as their main reasons for nonuse. ${ }^{3}$ Myths as a reason for nonuse varied across SubSaharan African countries: For example, in Kenya, 43\% of nonusers in 2008-2009 reported side effects and health concerns as their main reasons for nonuse, whereas in Senegal in 2010-2011, the figure was only 14\% (opposition by partners and others was the most common reason in this setting). ${ }^{3}$ This may reflect different contexts in the two countries: Kenya has higher overall contraceptive prevalence among women in and outside of union, whereas prevalence in Senegal is lower and predominantly among women in union

Other studies have demonstrated that myths and misinformation are often related to concerns about perceived side effects or perceived future infertility. ${ }^{7,11,14,15,24,25}$ For example, in Egypt and Kenya, fear of side effects or of having a baby with a deformity has been found to be positively associated with nonuse of modern contraceptives. ${ }^{11,15}$ Findings from Nigeria demonstrate that fear of side effects and concerns about long-term infertility are major reasons for not using modern contraceptives. ${ }^{14,24,25}$ Similar results were found in Mexico, where women who had never practiced contraception reported that they had chosen not to use the pill for safety reasons. ${ }^{8}$ In cases in which women express fear of health risks from practicing contraception, misinformation may be the real barrier.

In addition, belief of myths and misconceptions about family planning has been positively associated with contraceptive discontinuation and subsequent unmet need. ${ }^{6}$ According to findings from Mexico, a substantial proportion of urban women discontinued pill use because of fear of side effects. ${ }^{8}$ Although some contraceptive methods have recognized side effects, previous studies have shown that when women are informed of these side effects ahead of time, they are more likely to tolerate them and continue method use or to switch to another method, rather than discontinue use. . $^{26}$

To date, much of the research on contraceptive myths and misconceptions has focused on individual-level atti-

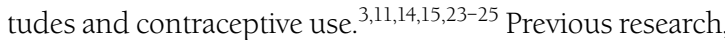
however, has not addressed the relationship between modern contraceptive use and the proportion of women or men in a community who believe in myths about family planning. Numerous studies focused on community-level health outcomes have examined whether socioeconomic status, supply environment and quality of health care are associated with a health behavior or outcome-that is, these studies have demonstrated that women's (or men's) behaviors are associated with the behaviors or attitudes of 


\begin{tabular}{|c|c|c|c|c|c|c|}
\hline \multirow[t]{2}{*}{ Myth } & \multicolumn{2}{|l|}{ Kenya } & \multicolumn{2}{|l|}{ Nigeria } & \multicolumn{2}{|l|}{ Senegal } \\
\hline & $\begin{array}{l}\text { Women } \\
(\mathrm{N}=5,684)\end{array}$ & $\begin{array}{l}\text { Men } \\
(\mathrm{N}=2,477)\end{array}$ & $\begin{array}{l}\text { Women } \\
(\mathrm{N}=9,130)\end{array}$ & $\begin{array}{l}\text { Men } \\
(\mathrm{N}=5,041)\end{array}$ & $\begin{array}{l}\text { Women } \\
(N=5,109)\end{array}$ & $\begin{array}{l}\text { Men } \\
(\mathrm{N}=2,244)\end{array}$ \\
\hline $\begin{array}{l}\text { Use of a contraceptive injection can } \\
\text { make a woman permanently infertile }\end{array}$ & 51.7 & 52.1 & 41.0 & 31.2 & 34.0 & 31.6 \\
\hline People who use contraceptives end up with health problems & 74.1 & 71.8 & 47.6 & 37.7 & 58.9 & 50.0 \\
\hline Contraceptives can harm your womb & 62.1 & na & 42.4 & na & 36.9 & 44.1 \\
\hline Contraceptives reduce women's sexual urge & 59.1 & 61.2 & 22.7 & 25.9 & 24.7 & 39.6 \\
\hline Contraceptives can cause cancer & 55.5 & 51.7 & 25.2 & 30.1 & 24.0 & 26.0 \\
\hline Contraceptives can give you deformed babies & 62.0 & 59.6 & 26.0 & 33.7 & 23.2 & 24.5 \\
\hline Contraceptives are dangerous to women's health & 71.5 & 68.0 & 46.6 & 43.2 & 50.2 & 43.8 \\
\hline $\begin{array}{l}\text { Women who use family planning/birthspacing } \\
\text { may become promiscuous }\end{array}$ & 35.0 & 40.2 & 23.0 & 25.7 & na & na \\
\hline $\begin{array}{l}\text { Family planning/birthspacing is women's business } \\
\text { and a man should not have to worry about it }\end{array}$ & na & 15.6 & na & 13.9 & & \\
\hline Mean (range)† & $4.6(0-8)$ & $4.3(0-8)$ & $2.7(0-8)$ & $2.5(0-8)$ & $2.6(0-7)$ & $2.8(0-7)$ \\
\hline
\end{tabular}

tThe average number of positive responses among eight (seven in Senegal) family planning myths. Notes: na=not applicable. All percentages are weighted and based on women and men who know at least one modern contraceptive method.

other who live around them. ${ }^{27-33}$ For example, Speizer et al. found that the increasing prevalence of sexual violence reported by women within a community was negatively associated with women's use of condoms at last sex and positively associated with their being HIV positive or having had an adolescent pregnancy; ${ }^{34}$ other studies among adults found similar results. ${ }^{27,35,36}$ And according to an analysis of 2005-2009 DHS data from 21 African countries, contraceptive use remained associated with community demographics and fertility norms, community-level gender norms and inequalities, and health knowledge after individual factors were controlled for. ${ }^{37}$

Understanding how belief of myths and misconceptions about family planning in a community-in the aggregate, as well as among individuals-are associated with contraceptive behaviors is important for the development of programs and policies that aim to increase contraceptive prevalence. Latent demand for family planning may be translated into actual use if programs can dispel false perceptions about contraceptives. Moreover, understanding the myths about family planning, which often reflect community norms and attitudes, will illustrate the importance of considering strategies that go beyond individuallevel knowledge and behavior change.

\section{METHODS}

\section{Data and Sample}

In 2009, the Bill \& Melinda Gates Foundation initiated the Urban Reproductive Health Initiative to increase contraceptive use in urban areas in four countries: India (Uttar Pradesh), Kenya, Nigeria and Senegal. For this study, we used data collected by the initiative's evaluation component, the Measurement, Learning \& Evaluation (MLE) project. In each study country, the MLE project collected baseline data from representative samples of women aged 15-49 and men aged 15-59 living in intervention cities purposely selected because of their need for increased modern contraceptive use: Nairobi, Kisumu and Mombasa in Kenya; Abuja, Ibadan, Ilorin and Kaduna in Nigeria; and
Dakar, Pikine, Guédiawaye and Mbao in Senegal.

Details on data collection can be found elsewhere. ${ }^{17-19}$ Briefly, a similar two-stage sampling design was used in each country, which aimed to include a representative sample of the urban poor, where possible. In Kenya, the 2009 national census frame was used to determine whether each primary sampling unit (PSU) was informal (no land tenure/slum) or formal (land tenure/nonslum). In Senegal, municipal leaders classified neighborhoods as poor or nonpoor on the basis of the characteristics of the majority of the households; the United Nations Habitat housing criteria (type of housing, residential security, neighborhood density, access to water and access to flush toilets) were used. Classified neighborhoods were linked to the census sampling frame before selection. In Nigeria, the 2006 census sampling frame was used, but there was no way to distinguish a PSU as poor or nonpoor before or after selection. For each study city in the three countries, a representative sample of PSUs was selected; where stratification by slum or nonslum was possible, half of selected PSUs were from each group.

A random sample of households was selected (30 per PSU in Kenya, 41 in Nigeria, and 21 in Senegal) on the basis of the listing and mapping conducted in the selected PSU, as well as other sampling criteria.* All women aged 15-49 who had spent the previous night in a selected household were eligible for interview; in half of selected households, all men aged 15-59 who had spent the previous night in the household were interviewed. In Kenya, 5,774 women and 2,503 men were surveyed; in Nigeria, 10,353 women and 5,547 men were surveyed; and in Senegal, 5,209 women and 2,270 men were surveyed.

*The PSUs come from the most recent census conducted in each of the countries. Since the census happened several years prior to our study, we conducted a presurvey exercise where we went to the selected PSUs to list all the households and to collect the geographic coordinates. The updated household list was used to select the households to participate in the study while the geographic coordinates were used to create maps that enabled the interviewers to easily locate the selected households during the main survey. The other sampling criteria were whether the cluster was poor vs. nonpoor or slum vs. nonslum. 


\begin{tabular}{|c|c|c|c|c|c|c|}
\hline \multirow[t]{2}{*}{ Myth } & \multicolumn{2}{|l|}{ Kenya } & \multicolumn{2}{|l|}{ Nigeria } & \multicolumn{2}{|l|}{ Senegal } \\
\hline & $\begin{array}{l}\text { Women } \\
(\mathrm{N}=287)\end{array}$ & $\begin{array}{l}\text { Men } \\
(\mathrm{N}=265)\end{array}$ & $\begin{array}{l}\text { Women } \\
(\mathrm{N}=339)\end{array}$ & $\begin{array}{l}\text { Men } \\
(\mathrm{N}=334)\end{array}$ & $\begin{array}{l}\text { Women } \\
(\mathrm{N}=155)\end{array}$ & $\begin{array}{l}\text { Men } \\
(\mathrm{N}=153)\end{array}$ \\
\hline $\begin{array}{l}\text { Use of a contraceptive injection can make a woman } \\
\text { permanently infertile }\end{array}$ & $\begin{array}{c}0.50 \\
(0.15)\end{array}$ & $\begin{array}{c}0.54 \\
(0.22)\end{array}$ & $\begin{array}{c}0.40 \\
(0.18)\end{array}$ & $\begin{array}{c}0.32 \\
(0.23)\end{array}$ & $\begin{array}{c}0.38 \\
(0.16)\end{array}$ & $\begin{array}{c}0.36 \\
(0.22)\end{array}$ \\
\hline People who use contraceptives end up with health problems & $\begin{array}{l}0.75 \\
(0.13)\end{array}$ & $\begin{array}{l}0.75 \\
(0.19)\end{array}$ & $\begin{array}{l}0.47 \\
(0.20)\end{array}$ & $\begin{array}{c}0.39 \\
(0.24)\end{array}$ & $\begin{array}{c}0.63 \\
(0.17)\end{array}$ & $\begin{array}{l}0.53 \\
(0.23)\end{array}$ \\
\hline Contraceptives can harm your womb & $\begin{array}{c}0.63 \\
(0.17)\end{array}$ & na & $\begin{array}{c}0.42 \\
(0.18)\end{array}$ & na & $\begin{array}{l}0.43 \\
(0.18)\end{array}$ & $\begin{array}{c}0.47 \\
(0.25)\end{array}$ \\
\hline Contraceptives reduce women's sexual urge & $\begin{array}{c}0.61 \\
(0.15)\end{array}$ & $\begin{array}{l}0.61 \\
(0.22)\end{array}$ & $\begin{array}{c}0.22 \\
(0.15)\end{array}$ & $\begin{array}{l}0.27 \\
(0.24)\end{array}$ & $\begin{array}{c}0.30 \\
(0.18)\end{array}$ & $\begin{array}{c}0.45 \\
(0.25)\end{array}$ \\
\hline Contraceptives can cause cancer & $\begin{array}{c}0.55 \\
(0.17)\end{array}$ & $\begin{array}{c}0.54 \\
(0.23)\end{array}$ & $\begin{array}{c}0.25 \\
(0.17)\end{array}$ & $\begin{array}{c}0.29 \\
(0.23)\end{array}$ & $\begin{array}{l}0.28 \\
(0.14)\end{array}$ & $\begin{array}{c}0.32 \\
(0.23)\end{array}$ \\
\hline Contraceptives can give you deformed babies & $\begin{array}{l}0.65 \\
(0.17)\end{array}$ & $\begin{array}{c}0.65 \\
(0.22)\end{array}$ & $\begin{array}{c}0.25 \\
(0.16)\end{array}$ & $\begin{array}{c}0.34 \\
(0.27)\end{array}$ & $\begin{array}{l}0.27 \\
(0.15)\end{array}$ & $\begin{array}{l}0.31 \\
(0.23)\end{array}$ \\
\hline Contraceptives are dangerous to women's health & $\begin{array}{l}0.71 \\
(0.15)\end{array}$ & $\begin{array}{c}0.71 \\
(0.22)\end{array}$ & $\begin{array}{l}0.23 \\
(0.18)\end{array}$ & $\begin{array}{c}0.45 \\
(0.27)\end{array}$ & $\begin{array}{c}0.54 \\
(0.19)\end{array}$ & $\begin{array}{l}0.48 \\
(0.24)\end{array}$ \\
\hline $\begin{array}{l}\text { Women who use family planning/birthspacing may } \\
\text { become promiscuous }\end{array}$ & $\begin{array}{c}0.31 \\
(0.16)\end{array}$ & $\begin{array}{c}0.43 \\
(0.22)\end{array}$ & $\begin{array}{l}0.46 \\
(0.20)\end{array}$ & $\begin{array}{c}0.28 \\
(0.23)\end{array}$ & na & na \\
\hline $\begin{array}{l}\text { Family planning/birthspacing is women's business } \\
\text { and a man should not have to worry about it }\end{array}$ & na & $\begin{array}{c}0.16 \\
(0.15)\end{array}$ & na & $\begin{array}{c}0.16 \\
(0.17)\end{array}$ & na & na \\
\hline Community level (aggregate) $\dagger$ & $\begin{array}{c}0.93 \\
(1.16)\end{array}$ & $\begin{array}{c}0.53 \\
(0.54)\end{array}$ & $\begin{array}{c}0.39 \\
(0.31)\end{array}$ & $\begin{array}{c}0.30 \\
(0.25)\end{array}$ & $\begin{array}{c}0.71 \\
(0.63)\end{array}$ & $\begin{array}{c}0.43 \\
(0.45)\end{array}$ \\
\hline Mean no. of observations per primary sampling unit (range) & $\begin{array}{l}20.1 \\
(6-37)\end{array}$ & $\begin{array}{l}9.0 \\
(5-21)\end{array}$ & $\begin{array}{l}30.5 \\
(6-61)\end{array}$ & $\begin{array}{l}16.3 \\
(5-40)\end{array}$ & $\begin{array}{l}33.6 \\
(11-62)\end{array}$ & $\begin{array}{l}14.8 \\
(5-37)\end{array}$ \\
\hline
\end{tabular}

Women and men with no knowledge of any contraceptive method were not asked questions on myths and misconceptions-our key independent variable-and were dropped from the analysis, along with those who chose not to answer any of the myth questions. In addition, women from PSUs that contained fewer than five women providing community-level information were excluded; men from PSUs that contained fewer than five men providing community-level information were excluded. The final analytic samples consisted of 5,588 women in Kenya, 8,880 women in Nigeria and 4,952 women in Senegal.

Study methods were approved by the institutional review board at the University of North Carolina at Chapel Hill and by in-country institutional review boards in Kenya, Nigeria and Senegal.

\section{Variables}

Our outcome of interest was women's use of a modern contraceptive method, measured by asking women if they were currently using a contraceptive method and, if so, which. We considered women to be currently using a modern method if they reported using the pill, IUD, injectable, implant, emergency contraceptive pills, lactational amenorrhea method, condoms (male or female), spermicide, diaphragm or sterilization (male or female).

The key independent variables were based on agreement with specific statements reflecting common myths and misconceptions about family planning. Examples of these statements include "use of a contraceptive injection can make a woman permanently infertile" and "people who use contraceptives end up with health problems"; they were informed by prior studies on barriers to family planning use and qualitative focus group discussions conducted during needs assessment studies in some of the study sites. ${ }^{10,11,38}$ Eight family planning myth statements were selected on the basis of cultural relevance for use in Kenya and Nigeria, and seven for use in Senegal. Response options included "strongly agree," "agree," "disagree" and "strongly disagree"; for each statement, a woman was coded 1 if she agreed or strongly agreed and 0 if she disagreed or strongly disagreed.

For the individual-level measure, we calculated the mean number of family planning myths with which a woman agreed or strongly agreed. For the community-level measures, we calculated the aggregated weighted proportion of myths with which women or men in PSUs agreed. To ensure an adequate sample size for community-level averages, we excluded PSUs with fewer than five women (for women's myths) or five men (for men's myths). The number of PSUs ranged from 153 for men in Senegal to 339 for women in Nigeria. Correlation between the women's individual-level variable and the women's community-level variable was low in all three countries (less than 0.10 in Kenya and Senegal, and 0.21 in Nigeria); however, the correlation between the women's and men's community-level variables was high in all three (0.77 in Kenya, 0.42 in Nige- 
ria and 0.58 in Senegal).

Other independent variables included woman's age (coded as seven five-year age-groups), education (none or Quranic, primary, secondary, higher than secondary and missing) and religion (Muslim, non-Muslim and missing); the small number of women in Nigeria and Kenya with missing data on religion or education were dropped from the analyses. In addition, analyses controlled for marital status (never married vs. ever married), wealth (quintiles calculated across the cities within countries using household assets, similar to how they are calculated in the DHS), ${ }^{39}$ and city of residence (for standardization, the capital city in each country was selected as the reference group).

\section{Analyses}

We used Stata version 12 for all analyses. Given a dichotomous outcome of interest, logistic regression was appropriate. We conducted three models: The first included the women's individual-level variable as the key independent variable, the second added the women's communitylevel variable to model 1 and the third added the men's community-level variable to model 2. All three models adjusted for sociodemographic characteristics and city of residence. In addition, all the models controlled for the country-specific clustered survey design, and all descriptive and multivariate analyses were weighted using the country-specific weights.

\section{RESULTS}

\section{Demographic Characteristics}

More than half of women in each country were aged 20-34 (69\% in Kenya, 56\% in Nigeria and 55\% in Senegal; Table 1 , page 192). Seventy-seven percent of women in Nigeria had a secondary or higher education; $58 \%$ of women in Kenya and 36\% in Senegal had that level of education. Ninety percent of women in Senegal were Muslim, whereas the same proportion in Kenya were non-Muslim; women in Nigeria were almost equally split between the two religions. The majority of women in each country were or had been married (60-68\%) and, as expected, women in each country were fairly evenly distributed between wealth quintiles. In Kenya and Senegal, the highest proportion of women lived in the capital city (75\% and 49\%, respectively), whereas in Nigeria, the highest proportions of women were from cities other than the capital (30\% from Ibadan and 29\% from Kaduna).

The proportion of women who reported current use of a modern contraceptive was $42 \%$ in Kenya, $27 \%$ in Nigeria and $17 \%$ in Senegal. In Kenya, the most commonly used modern methods were the injectable and the pill (17\% and $10 \%$, respectively; not shown), followed by male condoms ( $8 \%$ ). In Nigeria, male condoms and the injectable were the two most widely used modern methods ( $10 \%$ and $5 \%$, respectively); the next most widely used were the IUD and the pill (3\% each). In Senegal, the most commonly used modern methods were the pill and the injectable ( $5 \%$ each), followed by male condoms (3\%).

\begin{tabular}{|c|c|c|c|}
\hline Model & $\begin{array}{l}\text { Kenya } \\
(\mathrm{N}=5,128)\end{array}$ & $\begin{array}{l}\text { Nigeria } \\
(\mathrm{N}=8,377)\end{array}$ & $\begin{array}{l}\text { Senegal } \\
(N=4,562)\end{array}$ \\
\hline \multicolumn{4}{|l|}{ Model 1} \\
\hline Women's individual beliefs & $0.65(0.47-0.88)^{* *}$ & $0.27(0.22-0.34)^{* * *}$ & $0.22(0.17-0.29)^{* * * *}$ \\
\hline \multicolumn{4}{|l|}{ Model 2} \\
\hline Women's individual beliefs & $0.65(0.47-0.88)^{* *}$ & $0.26(0.21-0.32)^{* * *}$ & $0.22(0.17-0.29)^{* * *}$ \\
\hline Women's beliefs at community level & $1.01(0.96-1.05)$ & $1.43(1.14-1.79)^{* * *}$ & $1.04(0.74-1.45)$ \\
\hline \multicolumn{4}{|l|}{ Model 3} \\
\hline Women's individual beliefs & $0.64(0.47-0.88)^{* *}$ & $0.25(0.21-0.31)^{* * *}$ & $0.22(0.17-0.29)^{* * *}$ \\
\hline Women's beliefs at community level & $1.00(0.94-1.06)$ & $1.63(1.29-2.05)^{* * *}$ & $1.00(0.72-1.41)$ \\
\hline Men's beliefs at community level & $1.04(0.84-1.29)$ & $0.57(0.41-0.79)^{* * *}$ & $1.08(0.90-1.29)$ \\
\hline
\end{tabular}

\section{Levels of Belief in Myths}

In each country, the three myths most commonly endorsed by women (Table 2, page 193) were "people who use contraceptives end up with health problems" (48-74\%), "contraceptives are dangerous to women's health" (47-72\%) and "contraceptives can harm your womb" (37-62\%). For each myth, the proportion of women in agreement was highest in Kenya. Indeed, Kenyan women believed an average of 4.6 myths; the mean number of myths believed was 2.7 in Nigeria and 2.6 in Senegal (only seven myth statements were used in Senegal, as opposed to eight in the other two countries). The pattern among men was the same; the mean number of myths believed by men was 4.3 in Kenya, 2.5 in Nigeria and 2.8 in Senegal.

The same myth statements that were most prevalent among individuals were generally found to be most prevalent at the community level (Table 3, page 194). The community-level variable for women ranged from 0.39 in Nigeria to 0.93 in Kenya; the corresponding variable for men ranged from 0.30 in Nigeria to 0.53 in Kenya. As mentioned earlier, the correlation between women's and men's community-level scores was somewhat high, which means that a community in which a high proportion of women believe in myths will also contain a high proportion of men who believe in myths.

\section{Multivariate Analysis}

The number of family planning myths women believed was negatively associated with modern contraceptive use in the first regression model for each of the three countries (odds ratios, 0.2-0.7; Table 4). For example, in Kenya, a one-point increase in the number of myths believed by a woman was associated with a $35 \%$ decrease in her likelihood of using a modern method. The significance and magnitude of the individual-level variable were unchanged in each country when the female and male communitylevel variables were added sequentially in models 2 and 3 .

Community-level belief variables for women were not associated with modern contraceptive use in the second regression model for either Kenya or Senegal; when 


\begin{tabular}{|c|c|c|c|c|}
\hline Model & $\begin{array}{l}\text { Abuja } \\
(\mathrm{N}=1,872)\end{array}$ & $\begin{array}{l}\text { Ibadan } \\
(\mathrm{N}=2,720)\end{array}$ & $\begin{array}{l}\text { llorin } \\
(\mathrm{N}=2,124)\end{array}$ & $\begin{array}{l}\text { Kaduna } \\
(\mathrm{N}=1,640)\end{array}$ \\
\hline \multicolumn{5}{|l|}{ Model 1} \\
\hline Women's individual beliefs & $0.25(0.17-0.39)^{* * *}$ & $0.26(0.20-0.36)^{* * *}$ & $0.39(0.27-0.57)^{* * *}$ & $0.24(0.13-0.45)^{* * *}$ \\
\hline \multicolumn{5}{|l|}{ Model 2} \\
\hline Women's individual beliefs & $0.26(0.17-0.40)^{* * *}$ & $0.26(0.19-0.34)^{* * *}$ & $0.38(0.26-0.56)^{* * *}$ & $0.21(0.11-0.40)^{* * *}$ \\
\hline Women's beliefs at community level & $0.79(0.40-1.60)$ & $1.33(0.78-2.26)$ & $1.40(0.66-3.0)$ & $1.60(1.20-2.14)^{* *}$ \\
\hline \multicolumn{5}{|l|}{ Model 3} \\
\hline Women's individual beliefs & $0.26(0.17-0.40)^{* * *}$ & $0.26(0.19-0.34)^{* * *}$ & $0.39(0.27-0.57)^{* * *}$ & $0.23(0.12-0.44)^{* * *}$ \\
\hline Men's beliefs at community level & $0.55(0.16-1.82)$ & $1.46(0.83-2.56)$ & $0.61(0.32-1.16)$ & $0.53(0.32-0.90)^{*}$ \\
\hline \multicolumn{5}{|l|}{ Model 4} \\
\hline Women's individual beliefs & $0.26(0.17-0.41)^{* * *}$ & $0.25(0.18-0.34)^{* * *}$ & $0.36(0.24-0.53)^{* * *}$ & $0.19(0.09-0.37)^{* * *}$ \\
\hline Women's beliefs at community level & $0.92(0.45-1.91)$ & $1.20(0.69-2.11)$ & $3.29(1.25-8.66)^{*}$ & $1.87(1.36-2.59)^{* * *}$ \\
\hline Men's beliefs at community level & $0.60(0.16-2.28)$ & $1.33(0.75-2.38)$ & $0.33(0.15-0.71)^{* *}$ & $0.38(0.21-0.67)^{* * *}$ \\
\hline
\end{tabular}

analyses were restricted to women in union, the women's community-level variable attained significance for Senegal, but not for Kenya (not shown). In the third model that added the men's community-level variable, neither the male nor the female community-level variable was significant in either country.

In Nigeria, however, the women's community-level variable was positively associated with modern contraceptive use in model 2 (odds ratio, 1.4). The addition of the men's community-level variable in model 3 increased the magnitude of the women's variable (1.6); the men's variable itself was negatively associated with modern method use (0.6). Yet, when we ran a model with the men's community-level variable alone and controlled for women's individual-level myths, the association lost significance (not shown).

The results for Nigeria suggested the need for a more in-depth examination, so we conducted city-level analyses (Table 5). Model 1 included the women's individual-level belief variable, model 2 added the women's communitylevel belief variable to model 1, model 3 added the men's community-level variable to model 1 , and model 4 included all three variables; we controlled for women's demographic characteristics in all models. The women's individual-level variable was negatively associated with modern method use in all models for the four Nigerian cities (odds ratios, 0.2-0.4). As for the community-level variables, in Kaduna, belief in myths among women was positively associated with modern contraceptive use in both the model with the individual-level variable and the full model (1.6 and 1.9, respectively); the men's community-level variable was also significant, but the association was negative (0.4-0.5). In Ilorin, women's and men's community-level variables were not significant in models 2 and 3, respectively; however, both became significant in the full model, and the associations were in the same directions as found in Kaduna (3.3 for women and 0.3 for men). In Abuja and Ibadan, the women's and men's community-level variables were not significant in any model.

\section{DISCUSSION}

The main objective of this study was to examine associations between modern contraceptive use and individualand community-level agreement with myths about family planning in urban Kenya, Nigeria and Senegal. As expected, we found that at the individual level, women's belief in such myths was negatively associated with use of a modern contraceptive method. Previous studies have demonstrated this relationship. ${ }^{14,15,24}$

As for the community level, we found important country-specific differences. In Kenya, women's and men's belief in myths at the community level were not associated with modern contraceptive use, which may reflect Kenya's higher overall contraceptive use. Interestingly, Kenya had the highest proportions of women and men reporting agreement with family planning myths. This suggests that educational activities are needed in Kenya to address these myths.

In Senegal, as in Kenya, there was no association between women's and men's agreement with myths at the community level and modern contraceptive use among all women; however, our results suggest that agreement with myths at the individual and community level is negatively associated with contraceptive use among women in union. Given that most contraceptive use in Senegal is among women in union, ${ }^{19}$ it is not surprising that a communitylevel association was found for this specific group.

We found unexpected associations between community-level belief in family planning myths and women's modern contraceptive use in Nigeria: Increased community-level belief in myths among women was positively associated with contraceptive use, whereas increased community-level belief in myths among men was negatively associated with the outcome. When we examined these results at the city level, we found that Kaduna and Ilorin seem to be driving the relationships. One possible explanation of the positive associations among women in Kaduna and in Ilorin may be that these cities are rather conservative and Muslim, of the Hausa and Yoruba tribes, 
respectively. Compared with Abuja and Ibadan, which have more diverse populations, Ilorin and Kaduna are more ethnically and religiously homogenous, ${ }^{18}$ thus, women in Ilorin and Kaduna are more likely to have closely knit social networks within which myths and misconceptions about family planning can be spread and are more likely to report believing those myths and misconceptions, even though they may be using a modern method. Thus, the positive association between family planning myths and modern contraceptive use is plausible and highlights the fact that although these women had strong belief in myths, their need for contraception superseded any misconceptions about side effects of modern methods. With correct information about the mechanism of action and potential side effects of modern methods, the prevalence of modern contraceptive methods among these women could increase exponentially. Further research on the pathways through which myths and misconceptions spread within different cultural and religious populations is needed to identify appropriate ways to reduce those misconceptions.

\section{Limitations}

This study is not without limitations. First, we grouped women (and men) from a PSU to represent the aggregate belief in myths for individuals in that PSU, which is the standard approach for analyses of community-level influences using DHS data. ${ }^{27-29,37}$ However, the use of PSUs to represent urban communities may not have been the best strategy, because women in urban settings may be influenced by individuals outside of their community (e.g., where they work, shop and visit). Future analyses that examine the cohesion of urban communities will help determine how to define "community" in complex urban settings. Second, data on women's or men's beliefs in family planning myths may reflect what they see as socially desirable responses instead of their actual beliefs; this may have been the case in conservative locations, such as Kaduna and Ilorin in Nigeria. In addition, there may have been measurement error in collecting data on belief in family planning myths, especially in northern Nigeria. For example, in Kaduna, women were reluctant to agree or disagree with myth-related statements and were more comfortable answering questions about their own behaviors than expressing opinions about general statements. This led to more missing observations in Nigeria-the site with the lowest knowledge of family planning-and, thus, a larger number of women dropped from analyses.

\section{Program Implications and Perspectives}

Our findings suggest the need for family planning programs to target myths and misconceptions about modern contraceptive methods. Mass media can be used to improve knowledge of methods and to change social norms about use. ${ }^{40,41}$ Community mobilization and one-on-one counseling utilizing satisfied contraceptive users who can share their experiences are also ideal strategies to dispel pervasive myths. An additional strategy that is likely to reduce belief in myths, particularly among women, is the training of health workers to interact and share information with clients; these could be family planning clients or those seeking other maternal and child health services as part of integrated programming.

In places where community-level belief in myths about family planning was negatively associated with modern contraceptive use, programs are needed to encourage community-level discussions of such myths and of social norms related to contraceptive use. Programs in urban northern Nigeria (e.g., Kaduna and Ilorin) could consider strategies to improve interpersonal communication and discussion of accurate information to improve community-level attitudes. This could be achieved through the mass media (e.g., a radio drama), community outreach (e.g., street theater) or one-on-one counseling by outreach workers visiting households and communities to influence knowledge, attitudes, skills and practices related to family planning use.

Finally, findings from this study frame an agenda for future research, including the need of qualitative studies that can be used to better understand the role of myths on family planning use in Nigeria and the relationship between the attitudes of other community members (e.g., friends and neighbors) and a woman's decision to adopt a modern method. Focus group discussions, which are usually geared toward understanding community social norms, are needed-particularly in northern Nigeria-to help clarify the effect of and the pathways through which communitylevel norms influence individual behaviors and if the community-level effect is moderated by gender, especially in a patriarchal society such as Nigeria's. In-depth interviews with key informants-such as the leaders of women's community groups, religious and traditional leaders-can provide insights into the mechanisms through which myths are developed and through which they can be dispelled. And ethnographic studies could help our understanding of some of the cultural and societal underpinnings that influence the development and spread of these myths and misconceptions.

\section{REFERENCES}

1. Westoff CF, The potential demand for family planning: a new measure of unmet need and estimates for five Latin American countries, International Family Planning Perspectives, 1988, 14(2): 45-53.

2. Bradley SEK et al., Revising unmet need for family planning, DHS Analytical Studies, Calverton, MD, USA: ICF International, 2012, No. 25.

3. Sedgh G and Hussain R, Reasons for contraceptive nonuse among women having unmet need for contraception in developing countries, Studies in Family Planning, 2014, 45(2):151-169.

4. Singh S, Darroch J and Ashford L, Adding It Up: The Costs and Benefits of Investing in Sexual and Reproductive Health 2014, New York: Guttmacher Institute, 2014.

5. Creel LC, Sass JV and Yinger NV, Client-centered quality: clients' perspectives and barriers to receiving care, New Perspectives on Quality of Care, Washington, DC: Population Council and Population Reference Bureau, 2002, No. 2 
6. Ali MM, Cleland JG and Shah IH, Causes and Consequences of Contraceptive Discontinuation: Evidence from 60 Demographic and Health Surveys, Geneva: World Health Organization, 2012.

7. Lee J and Jezewski MA, Attitudes toward oral contraceptive use among women of reproductive age: a systematic review, Advances in Nursing Science, 2007, 30(1):E85-E103.

8. Grubb GS, Women's perceptions of the safety of the pill: a survey in eight developing countries. Report of the perceptions of the pill survey group, Journal of Biosocial Science, 1987, 19(3):313-321.

9. Castle S, Factors influencing young Malians' reluctance to use hormonal contraceptives, Studies in Family Planning, 2003, 34(3):186199

10. Ochako R et al., Barriers to modern contraceptive methods uptake among young women in Kenya: a qualitative study, BMC Public Health, 2015, 15(1):118.

11. Rutenberg N and Watkins SC, The buzz outside the clinics: conversations and contraception in Nyanza Province, Kenya, Studies in Family Planning, 1997, 28(4):290-307.

12. Paz Soldan VA, How family planning ideas are spread within social groups in rural Malawi, Studies in Family Planning, 2004, 35(4):275-290.

13. Yee $\mathrm{L}$ and Simon $\mathrm{M}$, The role of the social network in contraceptive decision-making among young, African American and Latina women, Journal of Adolescent Health, 2010, 47(4):374-380.

14. Ankomah A, Anyanti J and Oladosu M, Myths, misinformation, and communication about family planning and contraceptive use in Nigeria, Open Access Journal of Contraception, 2011, 2(1):95-105.

15. DeClerque J et al., Rumor, misinformation and oral contraceptive use in Egypt, Social Science \& Medicine, 1986, 23(1):83-92.

16. Hall MAK, Stephenson RB and Juvekar S, Social and logistical barriers to the use of reversible contraception among women in a rural Indian village, Journal of Health, Population, and Nutrition, 2008, 26(2):241-250.

17. Measurement, Learning \& Evaluation of the Urban Reproductive Health Initiative (MLE), Tupange, and Kenya Medical Research Institute (KEMRI), Report of the Baseline Household Survey for the Kenya Urban Reproductive Health Initiative (Tupange), Chapel Hill, NC, USA: MLE; and Nairobi, Kenya: Kenya Urban Reproductive Health Initiative (Tupange), and Kenya National Bureau of Statistics (KNBS), 2011.

18. MLE, Nigerian Urban Reproductive Health Initiative (NURHI) and National Population Commission (NPC), 2010-2011 Nigeria Baseline Survey for the Urban Reproductive Health Initiative, Chapel Hill, NC, USA: MLE, 2011

19. MLE and Initiative Sénégalaise de Santé Urbaine (ISSU), 2011 Baseline Survey for the Senegal Urban Health Initiative (ISSU) Household Survey: Final Report, Chapel Hill, NC, USA: MLE and ISSU, 2012

20. MLE, Measurement, Learning $\&$ Evaluation of the Urban Reproductive Health Initiative: Kenya, 2013 Mid-term Survey, [TWP 3-2013], Chapel Hill, NC, USA: MLE, 2013.

21. MLE, NURHI and NPC, Measurement, Learning \& Evaluation of the Urban Reproductive Health Initiative: Nigeria, 2012 Midterm Survey, Chapel Hill, NC, USA: MLE, 2013.

22. MLE et al, Les résultats de l'évaluation à mi-parcours du projet ISSU/ MLE. L'enquête auprès des ménages et l'enquête au niveau des points de prestations de services (PPS), Chapel Hill, NC, USA: MLE, ISSU, Agence pour la Promotion des Activités de Population-Sénégal and Global Research and Advocacy Group, 2014

23. Campbell M, Sahin-Hodoglugil NN and Potts M, Barriers to fertility regulation: a review of the literature, Studies in Family Planning, 2006, 37(2):87-98

24. Orji EO and Onwudiegwu U, Prevalence and determinants of contraceptive practice in a defined Nigerian population, Journal of Obstetrics \& Gynaecology, 2002, 22(5):540-543.

25. Otoide VO, Oronsaye F and Okonofua FE, Why Nigerian adolescents seek abortion rather than contraception: evidence from focus-group discussions, International Family Planning Perspectives, 2001, 27(2):77-81.

26. Bailey CE, Three Papers on Side Effects and Modern Contraceptive Use Among Women in Ghana, Southampton, UK: School of Social Sciences, University of Southampton, 2009.

27. Stephenson R et al., Contextual influences on modern contraceptive use in sub-Saharan Africa, American Journal of Public Health, 2007, 97(7):1233-1240.

28. Stephenson R and Tsui AO, Contextual influences on reproductive health service use in Uttar Pradesh, India, Studies in Family Planning, 2002, 33(4):309-320.

29. Stephenson R, Community influences on young people's sexual behavior in 3 African countries, American Journal of Public Health, 2009, 99(1):102-109.

30. Tuoane M, Diamond I and Madise N, Use of family planning in Lesotho: the importance of quality of care and access, African Population Studies, 2003, 18(2):105-132.

31. Oliver R, Contraceptive use in Ghana: the role of service availability, quality, and price, Living Standards Measurement Study Working Papers, Washington, DC: World Bank, 1995, No. 111

32. Magnani RJ et al., The impact of the family planning supply environment on contraceptive intentions and use in Morocco, Studies in Family Planning, 1999, 30(2):120-132.

33. Dinkelman T, Lam D and Leibbrandt M, Household and community income, economic shocks and risky sexual behavior of young adults: evidence from the Cape Area Panel Study 2002 and 2005, AIDS, 2007, 21(Suppl. 7):S49-S56.

34. Speizer IS et al., Sexual violence and reproductive health outcomes among South African female youths: a contextual analysis, American Journal of Public Health, 2009, 99(Suppl. 2):S425-S431.

35. Pallitto CC and O'Campo P, Community level effects of gender inequality on intimate partner violence and unintended pregnancy in Colombia: testing the feminist perspective, Social Science $\&$ Medicine, 2005, 60(10):2205-2216.

36. McQuestion MJ, Endogenous social effects on intimate partner violence in Colombia, Social Science Research, 2003, 32(2):335-345.

37. Elfstrom KM and Stephenson R, The role of place in shaping contraceptive use among women in Africa, PLoS ONE, 2012, 7(7):e40670.

38. Otoide VO, Oronsaye F and Okonofua FE, Why Nigerian adolescents seek abortion rather than contraception: evidence from focus-group discussions, International Family Planning Perspectives, 2001, 27(2):77-81

39. Rutstein SO and Johnson K, The DHS Wealth Index, DHS Comparative Reports, Calverton, MD, USA: ORC Macro, 2004, No. 6.

40. Bankole A, Rodriguez $\mathrm{G}$ and Westoff $\mathrm{CF}$, Mass media messages and reproductive behaviour in Nigeria, Journal of Biosocial Science, 1996, 28(2):227-239

41. Gupta N, Katende C and Bessinger R, Associations of mass media exposure with family planning attitudes and practices in Uganda, Studies in Family Planning, 2003, 34(1):19-31

\section{RESUMEN}

Contexto: Los mitos negativos y las ideas erróneas acerca de la planificación familiar son barreras para el uso de anticonceptivos modernos. La mayor parte de las investigaciones sobre este tema se han enfocado en las creencias individuales acerca de la anticoncepción; sin embargo, dado que los mitos se difunden fácilmente dentro de las comunidades, también es importante examinar cómo la prevalencia de mitos negativos en una comunidad afecta su nivel de uso de métodos.

Métodos: Se usaron datos de línea de base recolectados entre 2010 y 2011 por el proyecto Medición, Aprendizaje y Evalua- 
ción, provenientes de mujeres de 15 a 19 años que vivían en ciudades selectas en Kenia, Nigeria y Senegal. A través de análisis multivariado se examinaron las asociaciones entre el uso de anticonceptivos modernos y las creencias en mitos negativos por parte de personas y comunidades.

Resultados: En cada país, los mitos sobre planificación familiar más prevalentes a nivel individual y comunitario fueron "las personas que usan anticoncepción terminan teniendo problemas de salud", "los anticonceptivos son peligrosos para la salud de las mujeres" y "los anticonceptivos pueden dañar tu útero". En promedio, las mujeres en Nigeria y Kenia creían en 2.7 y 4.6 de ocho mitos seleccionados, respectivamente; en Senegal, creían en 2.6 de siete. A nivel individual, las creencias de las mujeres en mitos se asociaron negativamente con su uso de anticonceptivos modernos en los tres países (razón de probabilidades, 0.2-0.7). En Nigeria, la variable de mitos a nivel de la comunidad de las mujeres se asoció positivamente con el uso de anticonceptivos modernos (1.6), mientras que la variable de mitos a nivel de la comunidad de los hombres se asoció negativamente con el uso (0.6); En Kenia y Senegal, ninguna de las variables a nivel comunitario se asoció con el uso de anticonceptivos modernos.

Conclusiones: Se necesitan programas educativos para disipar mitos comunes e ideas erróneas sobre los anticonceptivos modernos. En Nigeria, pueden ser efectivos los programas que alienten las discusiones a nivel comunitario con el fin de reducir mitos y aumentar el uso de anticonceptivos modernos.

\section{RÉSUMÉ}

Contexte: Les mythes négatifs et les idées reçues sur la planification familiale font obstacle à la pratique contraceptive moderne. La plupart de la recherche sur la question se concentre sur les croyances individuelles au sujet de la contraception. Comme les mythes se propagent toutefois aisément dans les communautés, il importe aussi de considérer l'effet de la prévalence de mythes négatifs sur la pratique contraceptive.

Méthodes: Les données de base collectées en 2010-2011 dans le cadre du projet Mesure, Apprentissage et Évaluation (Mea- surement, Learning and Evaluation) concernant les femmes de 15 à 49 ans vivant dans certaines villes du Kenya, du Nigéria et du Sénégal sont utilisées. Les associations entre la pratique contraceptive moderne et les mythes négatifs acceptés au niveau individuel et communautaire sont examinées par analyses multivariées.

Résultats: Dans chaque pays, les mythes sur la planification familiale les plus répandus au niveau individuel et communautaire sont que «les personnes qui pratiquent la contraception finissent par avoir des problèmes de santé», «les contraceptifs nuisent à la santé des femmes» et «les contraceptifs peuvent endommager l'utérus». En moyenne, les Nigérianes et les Kényanes croient, respectivement, 2,7 et 4,6 sur huit mythes sélectionnés, et les Sénégalaises, 2,6 sur sept. La croyance individuelle des femmes à l'égard des mythes est associée négativement à leur pratique de la contraception moderne dans les trois pays (rapports de probabilités, 0,2-0,7). Au Nigéria, la variable mythe de niveau communautaire relative aux femmes est associée positivement à la pratique contraceptive moderne $(1,6)$, alors que celle relative aux hommes l'est négativement $(0,6)$; ni l'une ni l'autre n'est associée à la pratique contraceptive moderne au Kenya ni au Sénégal.

Conclusion: Des programmes d'éducation sont nécessaires pour dissiper les mythes courants et les idées reçues concernant la contraception moderne. Au Nigéria, les programmes qui encouragent la discussion communautaire semblent utiles à l'affaiblissement des mythes et à l'accroissement de la pratique contraceptive moderne.

\section{Acknowledgments}

This research was funded by the Bill \& Melinda Gates Foundation, and by a grant (5 R24 HD050924) awarded to the Carolina Population Center by the Eunice Kennedy Shriver National Institute of Child Health and Human Development. The funders had no role in study design, data collection and analysis, decision to publish or preparation of the manuscript. In addition, the contents of this paper are solely the responsibility of the authors and do not necessarily represent the official views of the funders.

Author contact: agueye@intrahealth.org 